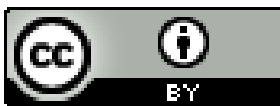

\title{
ESCRAVIDÃO E TRAJETÓRIAS DO PÓS-EMANCIPAÇÃO EM SÃO FRANCISCO DO CONDE: NOTAS DE PESQUISA (SÉCULOS XIX E XX).
}

\author{
Idalina M Almeida Freitas ${ }^{1}$ \\ Tatiana Florentino Santana ${ }^{2}$ \\ Elzira $S a^{3}$ \\ Juciara Viana ${ }^{4}$
}

\begin{abstract}
Resumo: Este texto busca apresentar notas de pesquisa cujo objetivo é traçar reflexões numa perspectiva histórica, acerca do município de São Francisco do Conde, localizado no recôncavo baiano, considerando o recorte temporal entre o final do século XIX e ao longo do século XX. Pretende-se refletir com base em fontes que denotam as experiências que caracterizaram os momentos finais do regime escravista e os destinos no pós emancipação de comunidades negras rurais, nos amparando em categorias tais como trabalho, família, gênero, geração e nos aportes teóricos da história social da escravidão e do trabalho. Num segundo momento, seguindo o rastro desses passados presentes, iremos traçar pequenas trajetórias de dois personagens negros e negras que contribuíram para pensar a história do município e as experiências no pós emancipação.
\end{abstract}

Palavras-chave: Comunidades negras; pós emancipação; recôncavo baiano; trabalho.

\footnotetext{
${ }^{1}$ Professora do Curso de História da Unilab, Campus dos Malês e do Bacharelado Interdisciplinar em Humanidades, líder do Grupo de Pesquisa O recôncavo baiano no Mundo Atlântico: história, memória e patrimônio. E-mail: idaensino@unilab.edu.br

${ }^{2}$ Discente do Curso de História da Unilab, Campus dos Malês. Pesquisadora do Grupo de Pesquisa O recôncavo baiano no Mundo Atlântico: história, memória e patrimônio. E-mail: tatisantana80@yahoo.com

${ }^{3}$ Discente do Bacharelado Interdisciplinar em Humanidades da Unilab, Campus dos Malês. Pesquisadora do Grupo de Pesquisa O recôncavo baiano no Mundo Atlântico: história, memória e patrimônio. Bolsista Fapesb. E-mail: saelzira23@gmail.com

${ }^{4}$ Discente do Bacharelado Interdisciplinar em Humanidades da Unilab, Campus dos Malês. Pesquisadora do Grupo de Pesquisa O recôncavo baiano no Mundo Atlântico: história, memória e patrimônio. E-mail: viana.jc.20@gmail.com
}

Revista da ABPN • v. 12, n. Ed. Especial - Caderno Temático: "Africanos, escravizados, libertos biografias, imagens e experiências atlânticas” • agosto de 2020, 


\title{
O
}

\section{SLAVERY AND POST-EMANCIPATION TRAJECTORIES IN SÃO FRANCISCO DO CONDE: RESEARCH NOTES (XIX AND XX CENTURIES)}

\begin{abstract}
This text seeks to present research notes whose objective is to trace reflections from a historical perspective, about the municipality of São Francisco do Conde, located in the recôncavo baiano, considering the time cut between the end of the 19th century and throughout the 20th century. The intention is to reflect on the basis of sources that denote the experiences that characterized the final moments of the slave regime and the destinies in the post emancipation of rural black communities, supporting us in categories such as work, family, gender, generation and the theoretical contributions of the social history of slavery and work. In a second moment, following the trail of these present pasts, we will trace small trajectories of two black and black characters who contributed to think about the history of the municipality and the experiences in the post-emancipation.
\end{abstract}

Keywords: Black communities; post emancipation; recôncavo baiano; work.

\section{TRAYECTORIAS DE LA ESCLA VITUD Y LA POSEMANCIPACIÓN EN SÃO FRANCISCO DO CONDE: NOTAS DE INVESTIGACIÓN (SIGLOS XIX Y XX)}

Resumen: Este texto busca presentar notas de investigación cuyo objetivo es trazar reflexiones desde una perspectiva histórica, sobre el municipio de São Francisco do Conde, ubicado en el recôncavo baiano, considerando el tiempo transcurrido entre finales del siglo XIX y a lo largo del siglo XX. La intención es reflexionar a partir de fuentes que denotan las experiencias que caracterizaron los momentos finales del régimen esclavista y los destinos en la posemancipación de las comunidades negras rurales, apoyándonos en categorías como trabajo, familia, género, generación y en los aportes teóricos de la historia social de la esclavitud y el trabajo. En un segundo momento, siguiendo el rastro de estos pasados presentes, trazaremos pequeñas trayectorias de dos personajes negros y negros que contribuyeron a pensar en la historia del municipio y las experiencias en la post-emancipación.

Palabras clave: Comunidades negras; abolición de puestos; recôncavo baiano; trabajo.

\section{ESCLA VAGE ET TRAJECTOIRES POST-ÉMANCIPATION À SÃO FRANCISCO DO CONDE: NOTES DE RECHERCHE (XIX ET XX SIÈCLES)}

Résumé: Ce texte vise à présenter des notes de recherche dont l'objectif est de retracer des réflexions d'un point de vue historique, sur la municipalité de São Francisco do Conde, située dans le recôncavo baiano, en considérant le temps écoulé entre la fin du XIXe siècle et tout au long du XXe siècle. L'intention est de réfléchir à partir des sources qui dénotent les expériences qui ont caractérisé les derniers moments du régime esclavagiste et les destins dans la post-émancipation des communautés noires rurales, en nous appuyant dans des catégories telles que le travail, la famille, le genre, la génération et dans les contributions théoriques de l'histoire sociale de l'esclavage et du travail. Dans un deuxième temps, en suivant la trace de ces passés présents, nous tracerons de petites

Revista da ABPN • v. 12, n. Ed. Especial - Caderno Temático: "Africanos, escravizados, libertos biografias, imagens e experiências atlânticas" • agosto de 2020, p. $563-590$ 
trajectoires de deux personnages noirs et noirs qui ont contribué à réfléchir sur l'histoire de la municipalité et les expériences de la post-émancipation.

Mots - clés: communautés noires; post-abolition; recôncavo baiano; travail.

\section{INTRODUÇÃO}

Esse texto é dedicado a memória e a história do Senhor Érico de Amorim, que faleceu no dia três de março deste ano, seu Amor, como era conhecido, tinha recém completado 102 anos, portanto, nosso personagem mais velho da pesquisa ainda vivo na época. Esse texto é também o registro de parte de suas memórias e de sua história, que são também fragmentos da história do Brasil.

DE MÃOS DADAS NO CHÃO DA HISTÓRIA E DA MEMÓRIA...

O projeto de pesquisa $O$ Recôncavo Baiano no Mundo Atlântico: história, memória e patrimônio, surgiu na Unilab/Campus dos Malês, que está situada no território de São Francisco do Conde, cidade da região metropolitana de Salvador. A universidade é composta por um corpo discente oriundo da região do Recôncavo Baiano e de países africanos de língua portuguesa, a saber: Angola, Guiné Bissau, São Tomé e Príncipe, Moçambique, Cabo Verde e Timor Leste. A pesquisa em si, envolve discentes do curso de História e Bacharelado Interdisciplinar em Humanidades, são em maioria mulheres negras estudantes/pesquisadoras e tem como principal objetivo realizar levantamento documental priorizando a tipologia escrita e oral, pensando o Recôncavo Baiano no contexto do Mundo Atlântico ${ }^{5}$. Na tipologia escrita nos apoiamos na bibliografia sobre a

\footnotetext{
${ }^{5}$ As possibilidades e vantagens de se lançar um olhar Atlântico visto de baixo para a história local do recôncavo baiano, pode oferecer elementos para reconstruir experiências históricas e de diferentes sujeitos, por meio de uma outra escala de observação. É possível perceber similaridades e diferenças, pensando o Atlântico como um espaço de conexões africanas, portuguesas e brasileiras, no qual cada uma das partes tem a sua importância e o seu papel. Pensar as articulações locais entre distintas regiões que compunham o oceano Atlântico, leva-nos a perceber aspectos demográficos, econômicos, políticos, sociais e culturais, articulando sempre as especificidades locais e a dinâmica geral. O mundo atlântico seria o encontro de mundos distintos, porém com experiências em certa medida, comuns. O conceito de história atlântica, busca a articulação entre o local e o global, fomentando pensar em especificidades regionais, levando sempre em consideração o contexto mais amplo de inserção. A economia atlântica interferia nas relações econômicas domésticas e a lógica de dominação desenvolvida nos quatro cantos do oceano também necessitava a
}

Revista da ABPN • v. 12, n. Ed. Especial - Caderno Temático: "Africanos, escravizados, libertos biografias, imagens e experiências atlânticas” • agosto de 2020, p. $563-590$ 
região e obras de referência acerca do tema da escravidão, liberdade e pós emancipação, em contextos similares. No trabalho com a história oral, buscamos realizar entrevistas livres, onde as pessoas relatavam suas histórias de vida e de seus familiares, pensando como essas trajetórias estão vinculadas aos passados - presentes desse território.

O interesse pela pesquisa de tais temas, foi sendo construído a partir das diversas inquietações desses discentes que encontravam poucas referências sobre a história do município e consequentemente as suas histórias, sobretudo as narrativas que envolvem trajetórias e gerações de famílias que sempre viveram naquele lugar. São histórias e memórias atravessadas pelo trabalho nas lavouras de açúcar, roças, mariscagem, pesca, caminhos de ferro e posteriormente o petróleo. São bairros e localidades que carregam ainda os mesmos nomes e referências à antigos engenhos e fazendas.

A investigação em fontes escritas foi realizada em diferentes acervos, Arquivo Público do Estado da Bahia (APEB), Biblioteca Pública do Estado da Bahia, Arquivo Municipal de Santo Amaro, Hemeroteca Digital (FBN), além do encontro com surpreendentes documentos pessoais, guardados em mãos de famílias locais. Consideramos importante o registro de documentos que foram disponibilizados gentilmente pelas famílias, os quais nos possibilitaram conhecer um pouco mais das histórias de personagens que não estão registrados na história e na memória oficial. Para a produção das fontes orais, entrevistamos pessoas mais velhas da região e ou familiares, seus descendentes, dando enfoque em suas trajetórias de vida, permeadas pelas dinâmicas de trabalho, conectadas a diferentes processos sociais, culturais e políticos importantes.

\section{SÃO FRANCISCO DO CONDE: PASSADOS PRESENTES}

São Francisco do Conde enquanto unidade administrativa, interliga a Região Metropolitana de Salvador à Cruz das Almas (através de Santo Amaro) e Alagoinhas (por via de São Sebastião do Passé), distando menos de vinte quilômetros da região de Feira de Santana (municípios de Amélia Rodrigues e Terra Nova). Enquanto território de identidade, São Francisco do Conde representa o vínculo terrestre entre a RMS e o

incorporação das elites locais, e por mais distantes que pudessem estar, a vivência local estava conectada ao contexto amplo desse espaço geográfico e humano.

Revista da ABPN • v. 12, n. Ed. Especial - Caderno Temático: "Africanos, escravizados, libertos biografias, imagens e experiências atlânticas" • agosto de 2020, 
Recôncavo (Santo Amaro), mantendo-se muito próximo ao Portal do Sertão (Amélia Rodrigues e Terra Nova). Essas populações são, majoritariamente, negras (pessoas autodeclaradas pretas e pardas). São regiões que abrigam uma ampla gama de modos de vida, atividades econômicas, arranjos socioculturais, práticas culturais e saberes locais, para além de um significativo conjunto patrimonial. Isso porque a constituição histórica do Recôncavo como um espaço diversificado e articulado produziu em todo o território um rico patrimônio, material e imaterial, que se faz presente na memória da arquitetura colonial das fazendas, sobrados, engenhos e usinas, nas edificações das antigas fábricas de charutos, tecido e azeite de dendê, nas estruturas das antigas linhas férreas e, principalmente na riqueza das práticas, manifestações e modos de vida de suas populações. No passado, a vila de São Francisco foi tida como um dos maiores redutos escravistas das Américas e nesse sentido, julgamos importante investigar essa história a partir de uma perspectiva crítica e levando em consideração as narrativas de outros sujeitos: homens e mulheres comuns.

O processo de ocupação da cidade de São Francisco do Conde, pode ser dividido em quatros momentos distintos: a obtenção de terras por Mem de Sá, as concessões de sesmarias que resultaram em construção de engenhos anterior a 1587, pela criação da freguesia de São Gonçalo de Sergipe do Conde anterior a 1588 e pela criação da vila de São Francisco em 1698. Segundo Schwartz, Mem de Sá era proprietário de uma vasta sesmaria no recôncavo, mais precisamente Sá era possuidor de 4 léguas de costa e 3/5 léguas terra adentro, 1 essas dimensões são correspondentes às terras que vão do Marapé até a ponta de Saubara. Mem de Sá dividiu a grande área em lotes e concedeu algumas sesmarias para: Fernão Rodrigues Castelo Branco: duas léguas, na entrada do Paraguaçu; Francisco Toscano:duas léguas; Egas Moniz Barreto: uma légua, acima da ilha dos franceses; Paulo Dias: meia légua, acima do rio Sergipe (do Conde); Sebastião Álvares: uma légua, defronte a ilha de Maré. Por volta de 1587, a sesmaria já noticiava a existência de cerca de 14 engenhos, que iniciaram o processo de povoamento de Sergipe do Conde: "Os engenhos surgiram antes das vilas e paróquias, e em grande parte do Recôncavo a primeira igreja da paróquia foi a capela de alguma dessas propriedades." (SCHWARTZ,1988, p. 92.)

Revista da ABPN • v. 12, n. Ed. Especial - Caderno Temático: "Africanos, escravizados, libertos biografias, imagens e experiências atlânticas" • agosto de 2020, 
Mem de Sá, em 1563, construiu neste território o "Engenho Real de Sergipe”, um dos maiores do Recôncavo e que possuía numerosos escravos para os serviços da lavoura da cana-de açúcar. Dentre as cinco vilas criadas pela Coroa, estava a Vila de São Francisco da Barra de Sergipe do Conde, que era constituída por doze freguesias, no decorrer dos anos a maioria delas foi desmembrada dos seus domínios, por meio de emancipação, reduzindo sua extensão territorial e permanecendo apenas três: São Gonçalo do Amarante (Sede), Nossa Senhora do Monte e Nossa Senhora do Socorro.

Quadro 1: Freguesias da Vila de São Francisco da Barra de Sergipe do Conde (1757)

\begin{tabular}{|c|c|}
\hline FREGUESIAS & ENGENHOS \\
\hline São Gonçalo(sede). & $\begin{array}{l}\text { Cajaiba, São José, Vanique, Marapé, Dom } \\
\text { João, Macaco das Pedras, Gurgainha, } \\
\text { Gurgaia, Colônia, Bananeiras, São Lourenço, } \\
\text { Buranhem, Capim Mirim, Fazenda do Meio, } \\
\text { Itatiguí, Piriquara, Macaco, Santa Clara, } \\
\text { Ladeira. }\end{array}$ \\
\hline Nossa Senhora do Monte Recôncavo. & $\begin{array}{l}\text { Guahyba, Engenho de Baixo, Engenho } \\
\text { D’Água, Povoado do Vencimento, Monte, } \\
\text { Paramirim, Cassarangongo, Quibaca, } \\
\text { Maracangalha, Cabaxi, Sapucaia, Pinheiro, } \\
\text { Pouco Ponto, Limoeiro, Grama, Lagoa, Santa } \\
\text { Cruz, Quissengo, Engenho Novo, Bonfim, } \\
\text { Mombaça, Mucury, Cravassú, Ilhas das } \\
\text { Fontes. }\end{array}$ \\
\hline Nossa Senhora do Socorro & $\begin{array}{l}\text { Santo Estevão, São Lourenço, Almas, Copa, } \\
\text { Cinco Rios, São Gonçalo, Pindoba, Piedade, } \\
\text { Mataripe, Barreto, Tanque, Cobé, São Paulo. }\end{array}$ \\
\hline
\end{tabular}

Fonte: Dias 2015, p.48 apud Pedreira, 1984, p.113-115.

A Vila de São Francisco da Barra do Sergipe do Conde foi elevada à categoria de cidade pelo decreto Estadual de 30 de março de 1938, passando a denominar-se São Francisco do Conde em 1943. Durante muito tempo, entre o apogeu e a crise dos engenhos e usinas de açúcar, a recuperação econômica da cidade só aconteceu a partir de 1947, com o início da exploração de petróleo e inauguração em 1950, da Refinaria Landulpho Alves Mataripe (RLAM), denominação em homenagem ao engenheiro e político baiano que articulou pela causa do petróleo no país e pela criação da Petrobrás na região.

Revista da ABPN • v. 12, n. Ed. Especial - Caderno Temático: "Africanos, escravizados, libertos biografias, imagens e experiências atlânticas" • agosto de 2020, 
Segundo Walter Fraga, o recôncavo não cultivava só cana de açúcar devido a variedade de solo que existe na região, tal variedade permitiu cultivos de vários produtos alimentícios como, mandioca, feijão, milho, fumo, além de outros gêneros de subsistência que contribuíam para o sustento ou abastecimento de Salvador e os pequenos centros urbanos da região, também propiciou a formação de pequenos grupos de subsistência por meio de comunidades negras rurais formadas ao longo de muito tempo (FRAGA FILHO, 2014, p.19).

No ano de 1885 a Subdelegacia da freguesia de São Gonçalo da Villa de São Francisco da Barra de Sergipe do Conde, registrava um caso de crime de lesões corporais, no lugar denominado Cortume. Júlia Africana, era maior de 50 anos e viúva, foi espancada por João Gonçalves, africano, também morador na vila. Sendo requerido ao delegado proceder o corpo de delito na ofendida e mais diligências em busca da punição do ofensor.

Por meio dos depoimentos das testemunhas, o nosso intuito é vislumbrar parte desse cotidiano entre a escravidão e a liberdade, bem como a inserção dessas pessoas, nas comunidades em que viviam, sobretudo nas dimensões que compreendem os espaços de circulação, a condição jurídica e o trabalho que exerceram como libertos. A primeira testemunha, tratou-se de Cirilo Jorge de Sant'Anna, de idade de cinquenta e um anos, que vivia de embarcar em seu próprio saveiro, conduzindo fretes para a capital. Cirilo era solteiro, morador na vila de São Francisco e natural da freguesia de Sant'anna da Ilha de Maré. Ao ser ouvido afirmou que não sabia o motivo da richa velha entre Julia e João, também disse que conhece os envolvidos a mais de vinte anos e que a convivência seria aparentemente pacífica, embora com alguns batimentos de boca. A segunda testemunha ouvida foi Felippe Pontes, africano livre de setenta annos de idade, que vivia de sua roça, também solteiro, morador na vila e natural da Costa d'África. Perguntado sobre a origem dos desentendimentos entre João e Julia, respondeu que João, sabendo que Júlia tinha dinheiro deixado pelo finado marido dela, confiava a quantia para algumas pessoas guardar. Ele alegava que Julia deveria deixar a quantia sob sua responsabilidade, pois ele como era africano da mesma nação da ofendida, seria de maior confiança.

Em seguida, compareceu Joaquim de Oliveira Mendes, cinquenta anos de idade, casado, morador na vila, vivia de sua lavoura e também era natural da Costa d'África. Em

Revista da ABPN • v. 12, n. Ed. Especial - Caderno Temático: "Africanos, escravizados, libertos biografias, imagens e experiências atlânticas" • agosto de 2020, p. $563-590$ 
depoimento, disse ser compadre do réu, ressaltando que mesmo com o parentesco, falaria a verdade do que lhe fosse perguntado. Sendo assim, respondeu que um dos dias da semana passada ao ocorrido, retornando por volta das cinco horas da tarde de sua roça na fazenda Campina, encontrou-se no caminho, dirigindo-se para a mesma Campina, João Gonçalves e este lhe disse que iria a roça arrancar mandioca com uma foice na mão $e$ um sacco na outra. A testemunha reprovou a atitude do compadre e o aconselhou:

(...) que aquelas horas já era tarde para arrancar mandioca, como porque estava muito armado de trovoado ameaçando a cahir, porém, o referido João Gonçalves não quis essas por deos conselhos e seguio, pouco depois, estando elle, testemunha em sua casa, lhe vierão dizer que naquela estrada estava o balaio de Julia com aipim, quiabos, cuias, tudo quebrado (...)

Por último, a quarta testemunha de nome Balbino Pontes, setenta anos de idade, vivia de sua lavoura, solteiro, morador na mesma vila, também natural da Costa d'África. Reconheceu que as ofensas proferidas por João eram graves, que a situação se originou de um encadeamento de fatos que se derão anteriormente nos entornos da fazenda Campinas desta freguesia, e que o réu ausentou-se logo após ocorrido o fato criminoso.

O crime registrado como de ofensas físicas, além de revelar as sociabilidades e desavenças entre dois africanos de mesma nação já livres do cativeiro, também expõe uma pequena dinâmica circunscrita a circulação entre fazendas da região, como foi mencionado o lugar Campina, antiga fazenda, hoje bairro de São Francisco.

O mosteiro de São Bento da Bahia, possui na freguesia de São Gonzalo e vila de São Francisco da barra de Sergipe do Conde a margem do rio Santo Amaro da Purificação um engenho denominado São Bento das lages com mais de duas mil tarefas, uma ilha ao lado da ponte, e uma fazenda por nome Campina sendo o limite do mesmo terreno, rio de Santo Amaro da Purificação, fazenda boa vista do senhor Manuel Joaquim de Azevedo pontes, terras do engenho São Jose, engenho de Macaco das Pedras, engenho Bananeiras, fazenda candangi e o terreno do mosteiro das Brotas. Engenho de São Bento das Lages 30 de Abril de $1855 .^{6}$

\footnotetext{
${ }^{6}$ Registro de terras públicas da Freguesia de São Gonçalo da Vila de São Francisco da Barra de Sergipe do Conde, 1855-1860. Arquivo Público do Estado da Bahia, APEB.
}

Revista da ABPN • v. 12, n. Ed. Especial - Caderno Temático: "Africanos, escravizados, libertos biografias, imagens e experiências atlânticas" • agosto de 2020, 
As vozes das testemunhas e as narrativas registradas por meio dos depoimentos também revelam elementos tais como: a idade do grupo de africanos livres, considerando ser um grupo de idosos em torno de 50, 60 e 70 anos de idade e que se conheciam a mais de vinte anos. Outro elemento importante é marcado pela nação, que embora não bem definida na fonte, é um elemento central na desavença dos envolvidos, uma vez que não houve colaboração e confiança, atitude exposta pela negativa da ofendida em lhe entregar o dinheiro para guardar. Segundo João Gonçalves, motivo pelo qual havia espancado Júlia. O cultivo das roças de subsistência, venda e circulação de produtos como aipim e quiabos, também sugere a permanência desses grupos em antigas fazendas e engenhos da região, provavelmente após a liberdade. No entanto, neste caso, não sabemos se esses sujeitos permaneceram de alguma forma ligados, pelos laços da escravidão a esses antigos senhores ou simplesmente pela convivência com amigos e familiares de nação.

Ainda segundo o historiador Walter Fraga, a condição de roceiro ou dono da roça, certamente era uma diferenciação no interior da comunidade, uma vez que este não dependia mais exclusivamente do trabalho na grande lavoura de cana, essa situação de conflitos vislumbradas nos processos crime, também nos permite verificar práticas de ajudas mútuas, como também divergências e tensões entre trabalhadores residentes nas proximidades dos grandes engenhos (FRAGA FILHO, 2006, p.304). Tal fragmento que visa dimensionar parte de um cotidiano relativo a vila de São Francisco no século XIX, nomeando e adentrando com mais intimidade as esferas das experiências e da sociabilidade de uma micro comunidade de africanos livres, só foi possível devido a identificação, coleta e transcrição de um conjunto de processos crime da região, levantados na pesquisa. Além dos processos, localizamos outros documentos que recriam a atmosfera dos momentos finais da escravidão na vila:

Nestes termos cabendo me a honra de responder á V. Exa. pela edilidade que inmerecidamente preside, devo a outrosim informar á V.Exa. que antes de terem notícia da definitiva apresentação do projeto de lei ao corpo legislativo quase todos os proprietários desta região haviam mantido incondicionalmente seos escravos e ingenuos, na supposição de que desta maneira obterão à retirada em massa das propriedades para a capital e poderiam organizar nosso trabalho. $\underline{\mathrm{Me}}$ parece que gozão dos ultimos proprietários o Coronel José Joaquim de Teive e Argollo e tenente coronel e vereador Constâncio de Queiroz, aliás reconhecidos pelo seo excelente espirito de caridade, e eu mesmo em sete de maio, aniversário

Revista da ABPN • v. 12, n. Ed. Especial - Caderno Temático: "Africanos, escravizados, libertos biografias, imagens e experiências atlânticas" • agosto de 2020, 
natalicio de um dos meus filhos assim procedi em relação à 346 indivíduos, sendo 203 escravos e 143 ingenuos, ainda existem nas três propriedades do engenho denominado Cassaragongo, Maracangalha e Mataripe, onde já habitam considerável número de antigos moradores e libertos anteriormente do meu casal. Portanto, ao ponto da libertação que se propôs a Lei sancionada em 13 de Maio, posso dizer à $\mathrm{V}$. Exa. com segurança que neste município a ninguém tomou de surpresa a sua promulgação, que nem os proprietários se illudirão com supposição de prazo nem os sujeitos aguardarão a solução legislativa; tudo já se anarchisou antes de tempo e tudo continua na maior confusão! ${ }^{7}$

O trecho acima é parte de um telegrama acerca da lei de 13 de maio de 1888, enviado à câmara da vila de São Francisco do Conde, para as mãos do Barão Muniz de Aragão, presidente da câmara à época. O telegrama enviado pelo Ministério de Agricultura, Comércio e Obras Públicas, sobre a referida lei, repercute entre os vereadores, senhores de engenho e donos de propriedades da região. Contudo, as principais considerações são feitas pelo barão, quando afirma não ser surpresa a promulgação da emancipação na vila, e não podendo mais conter a liberdade outorgada pela lei, ressalta que já moravam em sua propriedade considerável número de libertos. Como expôs Julio César em seu artigo, os escravos após serem libertos, teriam que cumprir um tempo obrigatório de serviços nas terras do ex-proprietário, alguns, sobretudo os escravos sexagenários, não ficaram totalmente livres.

A lei dos Sexagenários de 1871, embora fosse uma lei gradualista no processo de ruidez do regime escravista, impediria que senhores abandonassem seus ex- escravos idosos e incapazes, visto que este possuía a obrigação de cuidado, podendo usufruir dos serviços dos ex-cativos na medida de sua força (CESAR COSTA MANOEL, 2020, p.14) Essa lei de alguma forma reforçou o que o tal barão, ao ler esse telegrama, perante o estado "anárquico" que na sua concepção já se encontrava a vila, apela para a validação por meio de uma tal "força moral" que por ora, gozava um ou outro proprietário, mas cessando este paradeiro, a que vamos recorrer, que surte efeito contra a vadiação e o crime? ${ }^{8}$.

\section{BREVE ESTUDO DEMOGRÁFICO DA VILA DE SÃO FRANCISCO}

\footnotetext{
${ }^{7}$ Paço da Câmara Municipal da Villa de São Francisco da Barra do Sergipe do Conde, 19 de Maio de 1888. APEB. Grifo nosso.

${ }^{8}$ Idem.
}

Revista da ABPN • v. 12, n. Ed. Especial - Caderno Temático: "Africanos, escravizados, libertos biografias, imagens e experiências atlânticas” • agosto de 2020, p. $563-590$ 
Ao longo da coleta e análise das fontes, percorremos o Censo Demográfico de $1872^{9}$ realizado na Bahia. Em uma amostragem para o território que compreendia a Vila de São Francisco do Conde, destacamos as freguesias de São Gonçalo da Vila de São Francisco (a mesma que São Gonçalo do Amarante), Nossa Senhora do Monte, Madre de Deus de Boqueirão, São Sebastião das Cabeceiras do Passé e Nossa Senhora do Socorro do Recôncavo. Criamos tabelas para cada uma dessas localidades, priorizando os seguintes dados: homens livres e escravizados, mulheres livres e escravizadas, estrangeiros, escravos analfabetos, livres que sabiam ler e escrever, livres analfabetos, além dos ofícios mais comuns na vila: pescadores, lavradores, entre outros. A análise desse material é importante para compreendermos como era a vila e suas freguesias em fins do século XIX.

De acordo com este mesmo censo, em São Francisco foi averiguado um número expressivo de homens e mulheres livres na época. O recenseamento foi realizado e direcionado da seguinte forma: São Gonçalo da Vila de São Francisco, homens livres 2.072, mulheres livres 1.872 e homens escravos 141, mulheres escravas 100. Esse número de pessoas livres e escravizadas, correspondem os nascidos no Brasil. Na segunda tabela do documento a contagem apresenta-se da seguinte forma: homens livres 2.061, mulheres livres 1.864, homens escravos 191 e mulheres escravas 98. Nota-se no censo que os números divergem, demonstrando alteração entre a primeira e a segunda tabela ${ }^{10}$.

\footnotetext{
${ }^{9} \mathrm{O}$ Censo Geral do Império de 1872 apresenta uma preciosa e rica informação sobre o estado da população do Brasil à época do 2. Reinado. Os 12 volumes e mais de 8.500 quadros estatísticos retratam uma situação histórica vivida pelo país e também um momento na constituição dos serviços estatísticos do Estado brasileiro. A lei de 9 de setembro de 1870 que convocou o $1^{\circ}$ Censo decenal do Império criou paralelamente a Diretoria Geral de Estatística, o primeiro sistema centralizado de levantamento estatístico do Brasil. Feito que representou um momento importante da formação do Estado Nacional a partir dos elementos herdados da monarquia bragantina. A Diretoria Geral de Estatística do Império tornou-se, deste modo, o marco histórico inicial da estrutura do Sistema Nacional de Estatística, de que o IBGE, desde os anos trinta tem sido o elemento central. Fonte: https://biblioteca.ibge.gov.br/bibliotecacatalogo?id=225477\&view=detalhes
}

${ }^{10}$ É de suma importância sinalizar essa abordagem, pois nos permite uma compreensão ampla da população da vila de São Francisco nos momentos que antecedem a abolição no Brasil. Enquanto é perceptível ao examinar e explorar o censo, notamos que esse material apresenta algumas falhas no seu processo de coleta de dados. Levando a compreender que as autoridades da vila não se preocupavam e não davam a devida atenção ao recenseamento daquele ano. Estavam apreensivos, pois, reduziam que a contagem realizada em 1872 ia servir para determinar novos impostos, vindo a prejudicar seus negócios e para o recrutar seus escravos para servir a junta militar. Para saber mais sobre o assunto ver: BARICKMAN, B. J. E se a casa-

Revista da ABPN • v. 12, n. Ed. Especial - Caderno Temático: "Africanos, escravizados, libertos biografias, imagens e experiências atlânticas" • agosto de 2020, p. $563-590$ 
Os dados também mostraram que a vila de São Francisco tinha o menor número de ex-escravizados que sabiam ler e escrever, dando um total de $2.76 \%$ dos indivíduos, o restante quer escravizados ou livres eram analfabetos. Esses dados nos chamam a atenção pois é importante ressaltar que na mesma década de 70, a vila se lançava num grandioso empreendimento destinado a formação de “operários agrícolas". A primeira Escola Agrícola da Bahia, inaugurada em 15 de fevereiro de 1877, em São Bento das Lages, antigo Engenho das Lages, propriedade da Ordem de São Bento, teve origem no contexto pós-supressão do tráfico de escravos em 1850, dentre outras implicações que atingiram diretamente e reduziram a exportação do açúcar frente ao mercado mundial, consequência da falta de braços escravizados que mantinham o apogeu desse comércio. Tal empreitada contou com a articulação entre governo provincial, central e as elites açucareiras. A trajetória da $\mathrm{EAB}$ é um capítulo à parte na história da vila de São Francisco do Conde e do Brasil.

Ainda no que concerne o entendimento demográfico da vila, no final do século XVIII essa região abrigava 90\% dos 221 engenhos existentes na Bahia, durante todo o século XIX, os engenhos expandiram para todas as regiões agrícolas do Recôncavo, a qual produzia o açúcar que seria vendido em todo mercado mundial. Segundo o historiador José Pereira Neto (NETO, 2018, p.47) no ano de 1873 os engenhos multiplicaram no recôncavo, que abrigava 635 engenhos. Entre os moradores de São Francisco, das 40.879 pessoas, 29.843 eram livres, $73 \%$, e 11.036 escravos, 26,9\%, quase o dobro da média nacional cativa de $15,21 \%$ em 1872. Importante situar que no país, os livres formavam $84,78 \%$, quase $12 \%$ a mais do que em São Francisco do Conde, o que nos leva a afirmar que São Francisco foi uma cidade escravista até os momentos finais desse sistema. A questão demográfica em São Francisco do Conde, apresentava-se com a realidade racial de $35,35 \%$ declarados brancos, $43,01 \%$ pardos, $17,32 \%$ pretos e 4,31 indígenas. Juntando pardos e pretos, livres e escravos, 60,33\% da população (24.665) possuía descendência africana e afro-brasileira. Nacionalmente era 57,96\%. Os livres de

grande não fosse tão grande? Uma freguesia açucareira do Recôncavo Baiano em 1835. Afro-Ásia, nº 2930. Universidade Federal da Bahia.

Revista da ABPN • v. 12, n. Ed. Especial - Caderno Temático: "Africanos, escravizados, libertos biografias, imagens e experiências atlânticas" • agosto de 2020, p. 563-590 
cor eram 13.629, 33,33\%. Esses dados demonstram a expressiva hegemonia da população de raça negra em São Francisco do Conde no final do século XIX.

Interessante expor que a câmara municipal da vila de São Francisco do Conde, discutia no ano de 1876 a distribuição do eleitorado da dita freguesia, e a partir de uma demanda desta mesma câmara, acerca dos elementos para pensar o número de eleitores, encontramos esse importante dado:

Ilmo. Exmo. Sr.

Tendo a câmara municipal conhecimento por uma estatística, que corre impressa pelos jornaes da Bahia, que a freguesia de São Gonçalo desta Villa, na distribuição dos eleitores, baseado no recenseamento, caberão somente o número de dez eleitores, em vez de dezoito, que anteriormente dava, por ter sido compensado no cálculo para essa designação o número de 243 escravos, e não de 1827, como se prova pela certidão vista, julga de seo imperioso dever levar este facto à apreciação de VExa. na esperança de que dará as providências que o caso exige, para que não fique prejudicada a representação eleitoral da sobredita freguesia deste município, por quanto a população servil do mesmo modo que a população livre, formão os elementos para designação do número dos eleitores. Ora, sendo o número de livres recenseados, como consta nas publicações feitas 3954 , e da população escrava 1827 , perfazem a soma de 5781 - que na proporção de 400 para cada eleitor, da direito a 15 eleitores, e não dez, como erradamente publica a estatística mencionada. A esta supplica junta a Camara municipal os seos respectivos protestos da mais elevada consideração à Vexa.

Deos Guarde.

Ilmo. Exmo. Sr. Presidente da Provincia da Bahia

16 de Junho de $1876^{11}$

A câmara municipal da vila de São Francisco, ao tomar conhecimento de um mapa estatístico que circulava nos jornais baianos do ano corrente, onde baseado no recenseamento em vigor, a freguesia de São Gonçalo teria uma baixa no número de eleitores, contabilizando segundo o tal mapa, apenas o número de 10. Proporção que estaria diretamente relacionada a quantidade de pessoas escravizadas e livres. Alegava se que a estatística em circulação nos ditos jornais baianos era de 243 escravos e não de 1827, portanto, essa quantidade de eleitores precisaria ser revista. O número que a própria câmara da vila da São Francisco apresentava como o correto relativo a quantidade de escravos era 1827, ou seja, muito acima do que o censo de 1872 apontava, tal dado deste modo, apoiava o pedido de revisão e as providências a serem tomadas pelo governo da

\footnotetext{
${ }^{11}$ Paço da câmara municipal da Villa de São Francisco, 26 de Maio de 1876. APEB.
}

Revista da ABPN • v. 12, n. Ed. Especial - Caderno Temático: "Africanos, escravizados, libertos biografias, imagens e experiências atlânticas” • agosto de 2020, p. $563-590$ 
província no sentido de recontar o total de eleitores na freguesia para 15 e não 10 como fora veiculado.

No entanto, esse dado revela bem mais que um erro estatístico, para a nossa análise aqui, o dado fornecido pela câmara da vila de São Francisco do Conde, permite dialogar com Barickman, no sentido de comprovar que realmente a quantidade de escravos que o censo de 1872 apresentou para a freguesia de São Gonçalo era muito irrisório, no que diz respeito a realidade da posse de escravos na década de 1870 naquela vila. Vale ressaltar que essa controvérsia está associada apenas a uma freguesia da vila de São Francisco do Conde. Portando, como observou Barickman, o material referente ao censo apresentava falhas quanto a quantidade de pessoas escravizadas e livres, no entanto, era esse o material circulado pela imprensa baiana poderia refletir no pagamento de impostos e demais negócios na vila, no entanto, isso parece não ter mais importância, segundo nos mostra a solicitação da câmara, quando se tratava de questões que envolviam o processo eleitoral. Essa repercussão sobre o número de escravizados e livres e sobre o mapa estatístico com base no censo de 1872 na freguesia de São Gonçalo reforça de maneira direta que a vila de São Francisco do Conde, ainda em meados de 1888, era uma região fortemente escravista. Esses números se reverteram ao longo dos anos na formação de comunidades negras rurais após a abolição da escravatura e, junto a essas comunidades uma cidadania incompleta. No entanto, esses grupos já criavam seus significados de liberdade por meio de diferentes possibilidades de inserção social, reelaboração de suas identidades em territórios de circulação, como "moradores", "roceiros", "lavradores" num horizonte de expectativas muito aquém do que realmente deveria ser uma cidadania plena nas primeiras décadas da República.

\section{TRAJETÓRIAS E PERSONAGENS: GERAÇÕES DE FAMÍLIAS}

Ao longo da pesquisa, que ainda se encontra em curso, tivemos a ideia de construir um banco de dados de entrevistas, uma espécie de "acervo oral"12. Seguindo a premissa

\footnotetext{
12 Sabemos que o arquivo ou acervo oral são impropriamente empregados para designar os depoimentos orais gravados com fins documentais no decorrer de uma pesquisa, segundo Danièle Voldman. Porém para fins de projeto de pesquisa a longo prazo, de forma ambiciosa nos ancoramos em Verena Alberti quando explica: "No Brasil e em outros lugares onde a história oral se tornou um recurso metodológico reconhecido,
}

Revista da ABPN • v. 12, n. Ed. Especial - Caderno Temático: "Africanos, 
de explorar histórias de vida de personagens dessas comunidades negras de São Francisco do Conde, sobretudo aqueles mais idosos, pessoas que dedicaram suas vidas ao trabalho no campo, na roça, em obras públicas, usinas de açúcar, sindicatos, ferrovias, educação ou no marisco. Enfrentamos algumas dificuldades até aqui, como por exemplo: a falta de recursos em geral, como a carência de equipamentos especializados para o registro dos depoimentos, a dificuldade de deslocamento até as comunidades, pela ausência de transporte na universidade, além da própria dificuldade dessas pessoas, seja pelo estado de saúde ou da dinâmica dos familiares em nos disponibilizar um tempo em meio aos afazeres do cotidiano. No entanto, em sua maioria todos e todas foram bastante receptivas, nos abriram suas casas e suas memórias mais profundas, alegres, tristes e de muita luta ao longo de suas vidas. Nessa altura do texto, apresentaremos alguns desses personagens e buscaremos entender a partir de seus depoimentos, aspectos que dialogam com a história do município a luz do pós abolição.

A historiografia já a algum tempo vem apresentando interesse crescente pela memória coletiva e individual, justamente pensando na maneira como estas afetam as narrativas históricas, e consequentemente a forma como a história é lembrada, celebrada ou esquecida. As entrevistas que produzem as fontes para nosso projeto de pesquisa, seguem o rigor metodológico no qual o objeto de estudo do historiador é recuperado e recriado por intermédio da memória dos depoentes incorporando elementos ausentes de outras práticas históricas. (FERREIRA; AMADO, 2008, p.40). Nossa pesquisa busca conhecer um pouco da vida de personagens negros e negras no qual as constituições familiares se deram ao longo do tempo no mesmo território. Centramos o olhar e o foco nas narrativas que conduziam suas memórias pela experiência do trabalho, entrelaçadas

a institucionalização e a legitimação acadêmica colaboraram para a proliferação de iniciativas visando à constituição e à ampliação de acervos de entrevistas, que passaram a estar disponíveis à consulta de pesquisadores interessados. A formação desses acervos, muitas vezes é, ela mesma, justificativa para os investimentos em projetos de história oral, sob o argumento de que se constituem bens públicos. Está na base dessa argumentação não apenas a valorização do registro de experiências de vida, mas a premissa de que, uma vez gravadas, as entrevistas podem ser acionadas a partir de questionamentos que não estiveram na origem de sua produção. Para ver mais: ALBETI, Verena. Manual de História Oral, Rio de Janeiro: FGV, 2013; HEYMANN, Luciana e ALBERTI, Verena. Acervos de História Oral. Um patrimônio silencioso? In BAUER, Leticia e BORGES, Viviane Trindade (orgs.) História Oral e patrimônio cultural. Potencialidades e transformações. São Paulo: Letra e Voz, 2018; VOLDMAN, Danièle. Definições e usos. In FERRERIA, Marieta e AMADO, Janaína (orgs). Usos e abusos da História Oral. Rio de Janeiro: FGV, 2008.

Revista da ABPN • v. 12, n. Ed. Especial - Caderno Temático: "Africanos, escravizados, libertos biografias, imagens e experiências atlânticas" • agosto de 2020, 
por suas formas de produzir, morar, viver em família, regras de comportamentos, dentre outros aspectos. A exploração dessas reminiscências são bases comuns para o trato metodológico dos depoimentos orais reunidos (RIOS; MATTOS, 2005, p.9).

Nossos personagens têm em comum dentre outras coisas, a trajetória familiar construída no bairro de Paramirim. A localidade originou-se a partir da freguesia de Nossa Senhora do Monte, onde estava situado o engenho Paramirim, próximo a outros importantes engenhos como Engenho d'água, Madruga, Maracangalha, dentre outros. Nosso intuito aqui é apresentar uma amostragem inicial de 2 personagens negros que assim como tantos outros construíram a história de uma paisagem rural brasileira, onde a principal chave temática é o mundo do trabalho. No entanto, até o momento só recuamos até o início do século XX, período de nascimento deles. Nosso objetivo no aprofundamento da pesquisa é tentar recuar ainda mais no tempo e encontrar maiores detalhes sobre a genealogia dessas famílias negras, sendo assim, apostamos no trabalho metodológico com diferentes acervos.

Portanto nesse texto, não nos deteremos na análise minuciosa de todas as entrevistas, uma vez que o intuito nesse momento é pensar os elos em comuns entre as trajetórias de vida aqui apresentadas. Compreendemos que com esse esforço analítico inicial, por meio desse fio condutor, abriremos caminhos a fim de compreender em diferentes escalas, as trajetórias de lutas pela terra, melhores condições de trabalho e cidadania no Brasil.

\section{SENHOR ÉRICO DE AMORIM, O SEU AMOR DE PARAMIRIM.}

Figura 1: Senhor Érico de Amorim, o seu Amor como era conhecido, em entrevista concedida ao grupo de pesquisa no dia 19 de setembro de 2019, nos mostrou sua caixa com o álbum de fotografias da família, nesta foto apresentou sua mãe Maria Filipe de Amorim

Revista da ABPN • v. 12, n. Ed. Especial - Caderno Temático: "Africanos, escravizados, libertos biografias, imagens e experiências atlânticas" • agosto de 2020, 


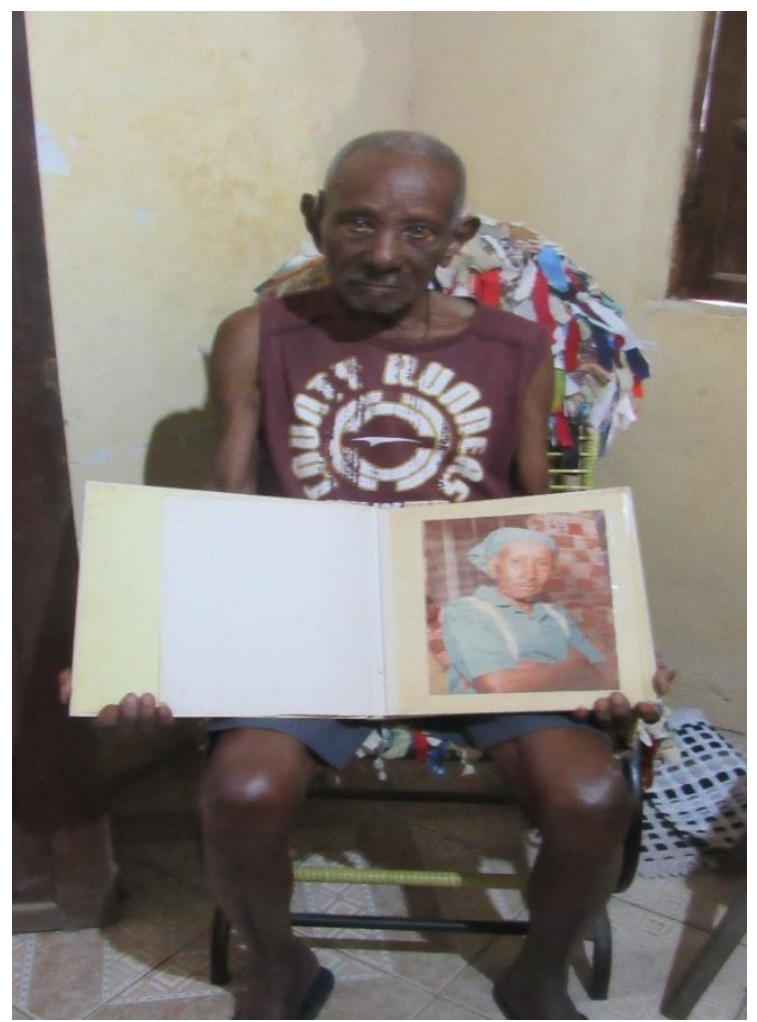

Fonte: Acervo do Grupo de Pesquisa O rcôncavo baiano no Mundo Atlântico: história, memória e patrimônio - UNILAB, setembro de 2019.

Érico de Amorim nasceu em Paramirim no ano de 1917, filho de Tomas Armando de Amorim e de Maria Filipe de Amorim. Era pai de doze filhos que, nos percalços da vida acabou perdendo três, ficando somente com nove filhos. Quando perguntado se havia estudado, disse que não estudou, segundo ele:

(...) não é que não tinha a escola, tem sim, porém eu preferia ficar trabalhando e ajudando o meu pai, tinha uma média entre oito a dez anos, para poder serrar colocava um banco e ficava em cima dele assim eu ajudava ele a fazer cadeiras. ${ }^{13}$

O pai de seu Amorim, era marceneiro e juiz de paz em Paramirim, ele se orgulha de ter herdado do pai o mesmo ofício, profissão que exerceu durante muito tempo onde era muito habilidoso, segundo ele, o pai tinha uma pequena tenda no povoado. Seu Amorim também trabalhou no corte e no carregamento de cana de açúcar com outros

\footnotetext{
${ }^{13}$ Entrevista Senhor Érico de Amorim, concedida no dia 19 de setembro de 2019, Paramirim, São Francisco do Conde.
}

Revista da ABPN • v. 12, n. Ed. Especial - Caderno Temático: "Africanos, escravizados, libertos biografias, imagens e experiências atlânticas” • agosto de 2020, 
companheiros. Conta sobre como era duro cortar a cana, jogar no "lombo do burro" e levar até as usinas da região, de lá um saveiro fazia o transporte para Salvador. Essa era a rotina de muitos trabalhadores do recôncavo nas primeiras décadas do século XX.

Seu Amorim também trabalhou na construção de estradas de ferro, primeiro na antiga usina Cinco Rios, distrito de Maracangalha. O engenho Maracangalha, que deu origem à usina já existia desde 1757. A Usina fechou e reabriu na década de 1930, passando para a administração de Álvaro Martins Catharino, sendo reaberta seis meses depois, porém não resistindo a sucessivas crises, voltando a fechar. No final da década de 1940 tendo à frente o Dr. Renato Augusto Novis um dos mais conhecidos dirigentes usineiros do Estado.Fechou novamente no ano de 1982, sendo reaberta por um grupo alagoano, tendo à frente o doutor Jarbas Araújo e por ele mesmo fechada definitivamente em abril de 1987. A construção da estrada que seu Amorim se refere fez parte da Estrada de Ferro Centro Oeste da Bahia (EFCOB), eram 8 quilômetros de linha férrea e uma pequena estação própria da Usina, juntamente com três locomotivas que realizavam o transporte da cana vindas de suas propriedades agrícolas.

Ele também trabalhou nos campos da Usina, em seu relato lembra que:

(...) na usina recebia dinheiro na hora após fim do trabalho, mas não fiquei por muito tempo na usina até porque trabalhava por fora não dentro, lembro que íamos a pé para trabalhar e quanto mais trabalhava mais dinheiro recebia, não lembro de muita coisa já fez muito tempo. ${ }^{14}$

Para muitos desses trabalhadores da Usina, a rotina nos campos começava logo cedo com a limpa da cana e a plantação. Alguns possuíam relação fixa de trabalho na empresa, em geral nos ofícios de cozinhador, soldador, evaporador, motorista, carpinteiro, caldeireiro, pedreiro, entre outros. Já uma outra parcela trabalhava de forma sazonal, nas épocas de corte da cana e transporte até a usina para a moagem. As mulheres trabalhavam no corte da cana nos campos. Algumas também foram professoras do/as filhos/as de trabalhadores em escolas no entorno. As atividades, em geral, eram penosas e o olhar

\footnotetext{
${ }^{14}$ Idem.
}

Revista da ABPN • v. 12, n. Ed. Especial - Caderno Temático: "Africanos, escravizados, libertos biografias, imagens e experiências atlânticas” • agosto de 2020, p. $563-590$ 
atento do feitor "lembrava o tempo dos engenhos", em uma memória ainda presente do período da escravidão. ${ }^{15}$

Na década de 50, seu Amorim trabalhou na Petrobrás, na chegada da refinaria á região, segundo ele, também trabalhou na construção da estrada que dava acesso a empresa "e ali nós não comia, cada um levava a sua comida de casa, só depois ao passar do tempo que começamos a comer no local do serviço". ${ }^{16}$ Essas terras onde a refinaria ocupou, eram as terras do antigo Engenho Mataripe, em São Francisco do Conde, e em 1957 passou a chamar-se Refinaria Landulpho Alves, nesse processo muitos pescadores, marisqueiros, pequenos agricultores e trabalhadores rurais, se envolveram numa outra experiência de trabalho braçal, mais aliada a tecnologia que a refinaria de Mataripe ofereceu (SANTOS, 2008, p.12).

Sobre o pequeno povoado de Paramirim, a partir de suas lembranças, respondeu o seguinte:

(...) que Paramirim era só lama a rua toda, quando chegava São João nós tirávamos a lama para poder colocar a lenha e fazer a fogueira, é na lama que fazíamos a nossa manifestação da festa porque era lama em tudo que é lado, depois vem melhorando aos poucos e resultou no atual Paramirim. ${ }^{17}$

Sobre as sociabilidades, seu Amorim lembra com carinho dos batuques $e$ capoeiras, que ele muito apreciava, embora não a praticasse, gostava muito de observar os movimentos precisos dos jogadores. Também afirmou que de vez em quando ia à missa na região, sobre religião e, que tinha muito apreço por Santo Antonio, São Roque, “pelos meninos” em referência à São Cosme e Damião e principalmente por São Benedito que era o santo da sua cor. As memórias de seu Amorim em relação ao pai são muito associadas ao trabalho, ainda sobre isso em certo momento ele menciona a relação do pai com a família Bulcão Viana, importantes proprietários de terras e donos de engenho na região. Ele diz que o pai era sempre obrigado a ir ás festas na casa de dona sinhazinha, eram as festas de São João na capela da fazenda. Embora tenha mostrado com orgulho a foto de sua mãe, seu Amorim não falou sobre ela, e finalizou: "naquele tempo os meninos não ficavam entre os mais velhos, se eles tivessem conversando, era pra passar longe".

\footnotetext{
${ }^{15}$ Referência ao livro de memórias de um ex-trabalhador da Usina Cinco Rios, In PAIVA. Neves Valdivino. Maracangalha: Torrão de Açúcar Talhão de Massapé. São Sebastião do Passé. 1996.

${ }^{16}$ Entrevista Senhor Érico de Amorim, concedida no dia 19 de setembro de 2019, Paramirim, SFC.

${ }^{17}$ Idem.
}

Revista da ABPN • v. 12, n. Ed. Especial - Caderno Temático: "Africanos, escravizados, libertos biografias, imagens e experiências atlânticas” • agosto de 2020, p. $563-590$ 
Figura 2: Registro da entrevista concedida pelo Sr. Érico de Amorim de 102 anos, morador de Paramirim em 19 de setembro de 2019 ao lado das discentes e pesquisadoras da UNILAB - Brenda Gabriele (BHI), Tatiana Santana (História) e Elzira

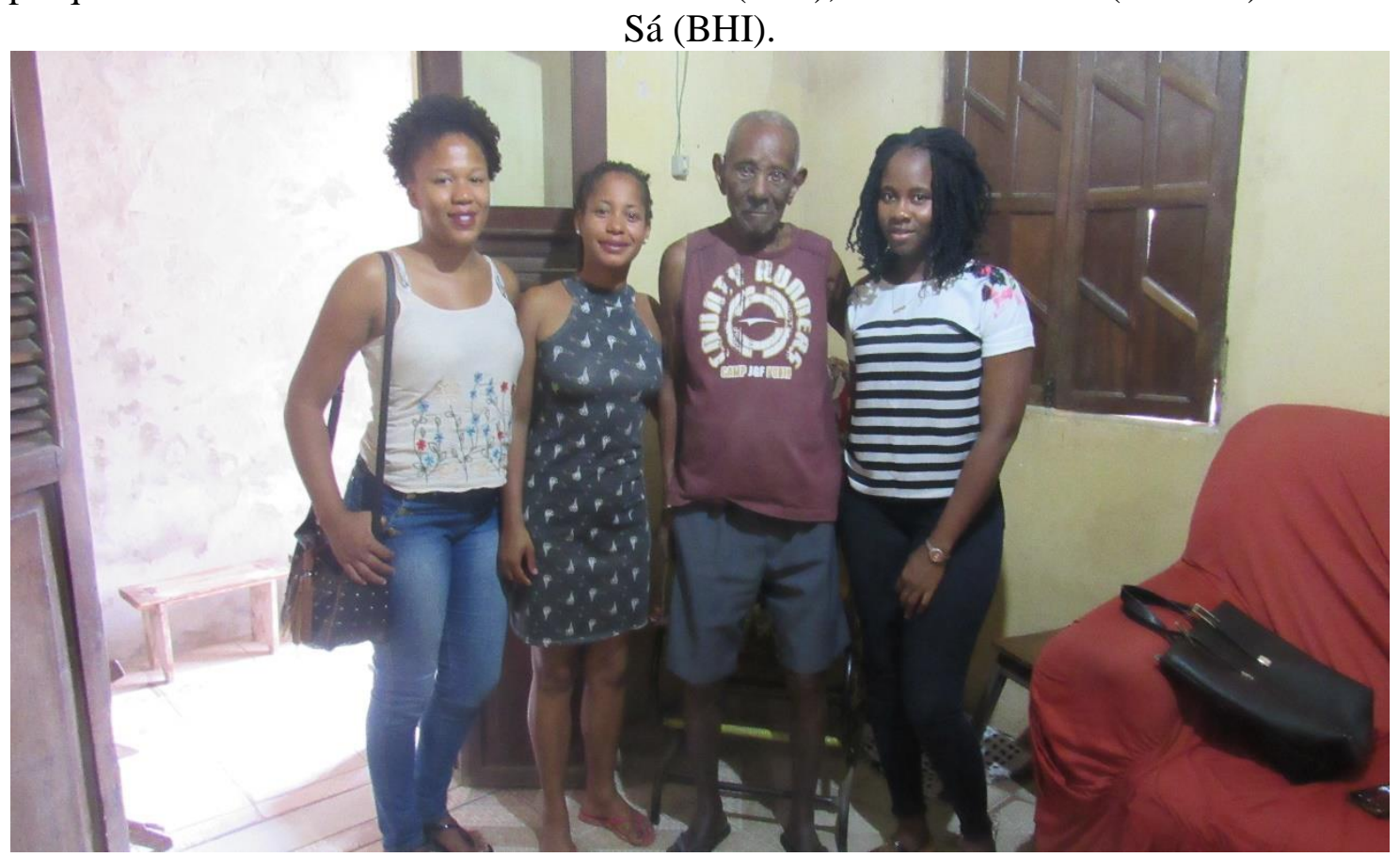

Fonte: Acervo do Grupo de Pesquisa O recôncavo baiano no Mundo Atlântico: história, memória e patrimônio - UNILAB, setembro de 2019.

QUINTINO DO NASCIMENTO: AGRICULTURA E POLÍTICA EM SÃO FRANCISCO DO CONDE

Quintino do Nascimento nasceu em 25 de Abril no ano de 1927 em São Francisco do Conde - Bahia. Foi trabalhador na Usina Cinco Rios entre as décadas de 60 á 80 e exerceu os cargos de feitor e administrador na usina Cinco Rios, em Maracangalha distrito de São Sebastião do Passé. A partir de documentos pessoais e do relato de Eliane Alcântara do Nascimento, 59 anos, conhecida como "Leninha" filha de seu Quintino, obtivemos algumas informações que revelam a sua trajetória. Quintino do Nascimento nasceu no Monte Recôncavo, seus pais eram de lá, aliás, toda a família. Com o passar do

Revista da ABPN • v. 12, n. Ed. Especial - Caderno Temático: "Africanos, escravizados, libertos biografias, imagens e experiências atlânticas" • agosto de 2020, p. $563-590$ 
tempo, quando ele tinha uns 6 a 8 anos, passou a morar no Vencimento ${ }^{18}$. Segundo ela,

Quintino frequentou a escola, mas teve que começar a trabalhar cedo:

Uns 10 anos, eu lembro quando era garotinha que ela falava que gostava mais de trabalhar com gado do que na roça, você sabe né, tudo era difícil naquela época. E escola para preto era complicado, papai falava de um professor que na hora que passava a sabatina e quem não acertasse tomava bolos nas mãos com a palmatória, mas não lembro o nome. Ele era muito bom em matemática. E naquele tempo tinha que ter caligrafia, não é hoje que temos que fazer riscos (risos), ele aprendeu a ler e escrever muito bem ${ }^{19}$.

Seu Quintino era um trabalhador diferenciado, segundo relatos, na matemática não perdia para ninguém, não fazia feio perante os engenheiros, não entrou para trabalhar na CEPLAC $^{20}$ pois não tinha como concluir os estudos. Depois que a família Clemente Mariani comprou a empresa, ele não se tornou funcionário, mas “dava uma lição para os engenheiros, explicava o que era tarefa de terra, medida e tal e tal,(risos)". ${ }^{21}$ Quando se casou, seu Quintino foi morar em Almas, pois já era funcionário da usina, e tinha direito a uma casa, segundo Leninha, eram "os mais chegados" que tinham esse direito. Por ser administrador na Usina Cinco Rios trabalhou no escritório em Salvador, fazia esse deslocamento por meio de um carro que o buscava em Maracangalha e o levava até Salvador, na rua dos Droguistas, no Comércio, cidade baixa.

(...) às vezes ele ia de cavalo para Cinco Rios, cada cavalos lindos e bem cuidados cedidos pela usina para papai ir trabalhar. Era muita confiança, ele quem fazia o pagamento dos trabalhadores, ia para o banco Central do Bradesco tirar uma boa

\footnotetext{
${ }^{18}$ A vila de São Francisco da Barra do Sergipe do Conde, quando foi inaugurada em meados do século XVII, pertenciam ao seu território as freguesias de Nossa Senhora do Monte Recôncavo, criada em 1608 pelo Bispo Dom Constantino Barradas. O Engenho Madruga situado na vila de São Francisco, foi um dos pioneiros entre os engenhos de açúcar do recôncavo, localizado nas terras férteis dos campos de Paramirim e Vencimento, às margens do rio Paramirim. In CUNHA, Mario Pinto. Memorial de São Francisco do Conde, Bahia, 1976. Importante ressaltar que faz parte do escopo dessa pesquisa o mapeamento dessas localidades que hoje são constituídas enquanto povoados e bairros no município de São Francisco do Conde, uma vez que o bairro do Coroado, que compreende hoje o que foi o antigo Engenho São Miguel e Almas, passou por algumas transformações que teve a atuação marcante de Quintino do Nascimento na distribuição das terras.

${ }^{19}$ Entrevista concedida por Eliane Alcântara do Nascimento, 59 anos em maio de 2019.

${ }^{20}$ Comissão Executiva do Plano da Lavoura Cacaueira - CEPLAC, órgão do Ministério da Agricultura, Pecuária e Abastecimento, com sua direção geral localizada em Brasília-DF, atua em seis estados do Brasil: Bahia, Espírito Santo, Pará, Amazonas, Rondônia e Mato Grosso. Criada em 20 de fevereiro de 1957, época em que a economia cacaueira atravessava uma grave crise, teve sua atuação, nos seus primórdios, centrada basicamente no apoio à cacauicultura. Fonte: http://www.ceplac.gov.br/paginas/ceplac/ceplac.asp

${ }^{21}$ Entrevista concedida por Eliane Alcântara do Nascimento, 59 anos em maio de 2019.
}

Revista da ABPN • v. 12, n. Ed. Especial - Caderno Temático: "Africanos, escravizados, libertos biografias, imagens e experiências atlânticas” • agosto de 2020, p. 563-590 
quantia para fazer o pagamento dos funcionários. Naquela época ele era muito requisitado e adorado pelos donos da Usina Cinco Rios, é a todos que vão dar essa confiança?

Segundo a filha, seu Quintino era um homem que "só andava com ouro”, anéis, relógios, tudo era de ouro. Era uma necessidade ele andar bem arrumado, tinha um cargo importante e só andava no "meio dos politicos". O cotidiano era agitado, ele trabalhava na Usina Cinco Rios no escritório em Salvador na Cidade Baixa e alguns dias em Maracangalha, além de dedicar o pouco tempo livre que tinha para a política.

A família morava na fazenda São Miguel e Almas, propriedade da família de Celso Bulcão que vendia canas para usina Cinco Rios e muitas pessoas que moravam em Almas trabalhavam na usina também. Sua esposa era professora dos filhos dos trabalhadores da usina, nas dependências da propriedade ou nas localidades próximas. Dona Maria Alcântara do Nascimento, conhecida como Dona Bia, atualmente com 98 anos. Ela ensinava os meninos e meninas a ler, as meninas a fazerem "bolo confeitado, bordar e costurar, ela era muito exigente" ${ }^{\prime 22}$.

Depois que a família mudou para o povoado de Paramirim, dona Maria Nascimento começou a lecionar na escola do Madruga ${ }^{23}$, foi a primeira professora desse local. Às vezes as crianças não iam tomar a lição porque tinham que ir para roça, pegar água com seus pais, quando os filhos faltavam, ela tomava a lição depois. A escola era um local improvisado, tinha umas tábuas para fazer um banco para os meninos e as meninas, o amigo dela deu dois bancos prontos.

Os irmãos de Quintino foram embora para Salvador, mas ele não quis ir, gostava muito do lugar onde morava, também tinha vários amigos do meio político, por exemplo, Dr. Porciúncula, e fez até campanha para Jânio Quadros na década de 60. Sobre a relação com a família Clemente Mariani, havia uma confiança em Quintino, ele trabalhava no escritório e mexia com dinheiro, "para você ver como era", adverte Leninha. Como diretor administrativo na usina, durante a semana ele ia para Salvador e para

\footnotetext{
22 Idem.

${ }^{23}$ O Engenho Madruga situado na vila de São Francisco, foi um dos pioneiros entre os engenhos de açúcar do recôncavo, localizado nas terras férteis dos campos de Paramirim e Vencimento, às margens do rio Paramirim. In CUNHA, Mario Pinto. Memorial de São Francisco do Conde, Bahia, 1976. Pp.45.
}

Revista da ABPN • v. 12, n. Ed. Especial - Caderno Temático: "Africanos, escravizados, libertos biografias, imagens e experiências atlânticas” • agosto de 2020, p. $563-590$ 
Maracangalha aos sábados. Mais uma vez Leninha destaca a elegância do pai em seu trajar:

Ele só andava com os sapatos lustrados, com as roupas bonitas, pois, comprava tudo no comércio, trabalhava lá perto. Imagina um homem que só fez a quarta série, chamava escola leiga, e ficava no meio de gente importante. Ele era muito comunicativo e todos tinham a confiança nele, sabia que poderia confiar nele e no trabalho. Olha naquela época um homem negro exercendo funções importantes, como trabalhar no escritório da usina e ser vereador social, poucos sabem disso. ${ }^{24}$

Sobre a trajetória política de Quintino do Nascimento por meio de alguns documentos pessoais identificamos que na data de 30 de abril no ano de 1959 ele foi nomeado pelo governador do estado da Bahia, como Juiz de Paz no distrito de Monte de Recôncavo, no termo de São Francisco do Conde.

Quintino foi vereador municipal em diversas legislaturas nas décadas de 60, 70 e 80, conforme consta em seus diplomas. Segundo seu Manoel Amorim, 72 anos, professor no município de Candeias e primo de Quintino, nas décadas de 70, conhecido como "vereador social onde não recebia nada", ele mesmo conta que foi vereador 03 vezes em Candeias e também vice-prefeito e ressalta esse histórico das pessoas que naquele período participavam da política sem receber salário. Em seu relato chama a atenção para o fato de a pequena Paramirim possuir dois vereadores nessas condições:

Porque alí em Paramirim teve 02 elementos que dentro daquele período dominava aquela região, ele e Humberto, certo? Interessante que Paramirim daquele tamanhinho tinham 02 vereadores, quando eram 09 vereadores aqui e tinha 02. Não tinha Coroado, o Coroado foi uma criação de Quintino, certo? Através desse processo da prefeitura, porque ali é dividido de Nelson Bulcão e a outra parte era ele, aí ele pegava o livrinho dele aqui, ele tinha aquele espaço com relação a questão cartorial, certo? ${ }^{25}$

Seu Manoel é enfático ao afirmar que Quintino do Nascimento fundou o bairro do Coroado, que o mesmo participou de todo o processo onde se originara. a partir da

\footnotetext{
${ }^{24}$ Entrevista concedida por Eliane Alcântara do Nascimento, 59 anos em maio de 2019.

${ }^{25}$ Entrevista concedida pelo Senhor Manoel Amorim, 72 anos, em junho de 2019.
}

Revista da ABPN • v. 12, n. Ed. Especial - Caderno Temático: "Africanos, escravizados, libertos biografias, imagens e experiências atlânticas” • agosto de 2020, 
expropriação de moradores das localidades de Candeias, Mataripe, dentre outros espaços, ocupados pela Petrobrás, quando esta começara as suas atividades na região. ${ }^{26}$

(...) por trás muita gente não sabe, ele fazia o jogo, correto, ele fazia até o jogo com pessoas comunistas, certo. Ele tinha um amigo em Candeias, chama Cassimiro Correia que era presidente do sindicato ruralista, os agricultores dessa região toda aqui, correto, invasão de terra e a zorra toda, ele por trás fazia parte, tá vendo? Todo de branco, com seu guarda-chuva, perfumado, o negão só andava todo perfumado ( risos), entendeu, mais tinha essa...a índole do cara, dele era servir, era servir, ele não tinha aquela de... ele sabia que fazendo esses favores, certo... ele teve outro que o cara era do Socorro que era leigo, foi meu colega inclusive de câmara de Candeias, chama Bento de Souza, certo, que eles ganhavam as eleições neste critério, nesse método, entendeu? ${ }^{27}$

As informações acerca de Quintino do Nascimento obtidas por meio do depoimento de seu primo Manoel Amorim denotam sua atuação política combativa, porém numa dinâmica de negociação, em 1964 período em que a cidade de São Francisco do Conde foi declarada como área de segurança nacional (ASN), ele fala que mesmo "debaixo do pano", Quintino se manteve no grupo de vereadores que desejavam emancipar a cidade dessa condição. Por fim, seu Manoel faz algumas reflexões sobre a questão agrária na região e afirma:

(...) a respeito da questão agrícola de São Francisco do Conde onde Quintino teve uma grande participação muito grande dentro daquela região, certo, que depois todo mundo plantava dentro daquela área toda, toda aquela parte da fazenda, hoje descendo ali, certo? Alí em Almas. Dentro daquela região por exemplo, Madruga, Vencimento, tudo na realidade quem fazia era Quintino velho, para o pessoal ter seus espaços. Então, a parte de lá de cima, certo, toda parte inclusive a da refinaria, onde tem o trevo aquela área toda dali era plantada agrícola. A Petrobrás tomou tudo de todo mundo, hoje você está vendo todo mundo voltando, e quem participava disso aqui? Quintino do Nascimento. ${ }^{28}$

\footnotetext{
${ }^{26}$ Sobre a emergência da Petrobrás na região de Candeias e do recôncavo, a descoberta do petróleo nessas terras ganhou importância numa dimensão nacional, entre 1949 e 1950 as terras situadas entre os rios São Paulo e Mataripe, a 6 kilômetros de Candeias ergueu-se a Refinaria Nacional de Petróleo, comumente chamada de Refinaria Mataripe que em 1957, passou a chamar-se RLAM - Refinaria Landulfo Alves. O Jornal Diário de Notícias informava que em 23 de junho de 1952, Vargas visitou os campos petrolíferos da Bahia. No ano seguinte a sua visita a Candeias, através da lei 2004, de 03 de outubro de 1953, Getúlio Vargas criou a Petrobrás, que passou a ter o monopólio estatal da pesquisa, lavra, refino e transporte de petróleo no Brasil. In SANTOS, Jair Cardoso dos. Candeias. História da Terra do Petróleo. Gráfica Salesiano, Salvador, 2008, pp. 125-130.

${ }^{27}$ Entrevista concedida pelo Senhor Manoel Amorim, 72 anos, em junho de 2019

${ }^{28}$ Idem.
}

Revista da ABPN • v. 12, n. Ed. Especial - Caderno Temático: "Africanos, escravizados, libertos biografias, imagens e experiências atlânticas” • agosto de 2020, p. $563-590$ 
Quintino também participou de alguns cursos, como o de treinamento gerencial promovido pela Conder - Conselho de Desenvolvimento do Recôncavo, criado em 1967 afim de delimitar a área metropolitana de Salvador. No ano de 1996 falece no município e no dia 18 de junho do mesmo ano, a câmara registra uma moção de pesar onde destaca os feitos do servidor municipal. Ainda na sala de sessões da câmara, desta vez no ano de 2001, o vereador Manoel Carlito Cerqueira, solicita a câmara por meio de requerimento e indica a mesa diretora que a escola de primeiro grau no povoado de Paramirim estando concluída e prestes a entrar em funcionamento, receba o nome de Quintino do Nascimento, tendo em vista que o munícipe foi um cidadão de conduta ímpar, dedicado funcionário da prefeitura e vereador por diversas legislaturas. ${ }^{29}$

Para nós historiadoras, as trajetórias de trabalhadores como Érico Amorim e Quintino do Nascimento, põem em diálogo e intersecções campos de pesquisa e metodologias que nos ajudam a recuperar histórias vislumbrando dimensões de vida do campesinato e operariado negro da região, entendendo as complexidades de suas trajetórias, articulações e lutas.

Figura 2: Quintino Nascimento, fotografia cedida por sua filha Eliane, sem data.

29 Câmara de Vereadores de São Francisco do Conde, indicação n 008/2001, assunto: denominação de próprio municipal. Sala das sessões, 18 de janeiro de 2001. Documentos pessoais de Quintino do Nascimento, cedidos e autorizados para pesquisa científica por sua filha Eliane Alcântara do Nascimento

Revista da ABPN • v. 12, n. Ed. Especial - Caderno Temático: "Africanos, 

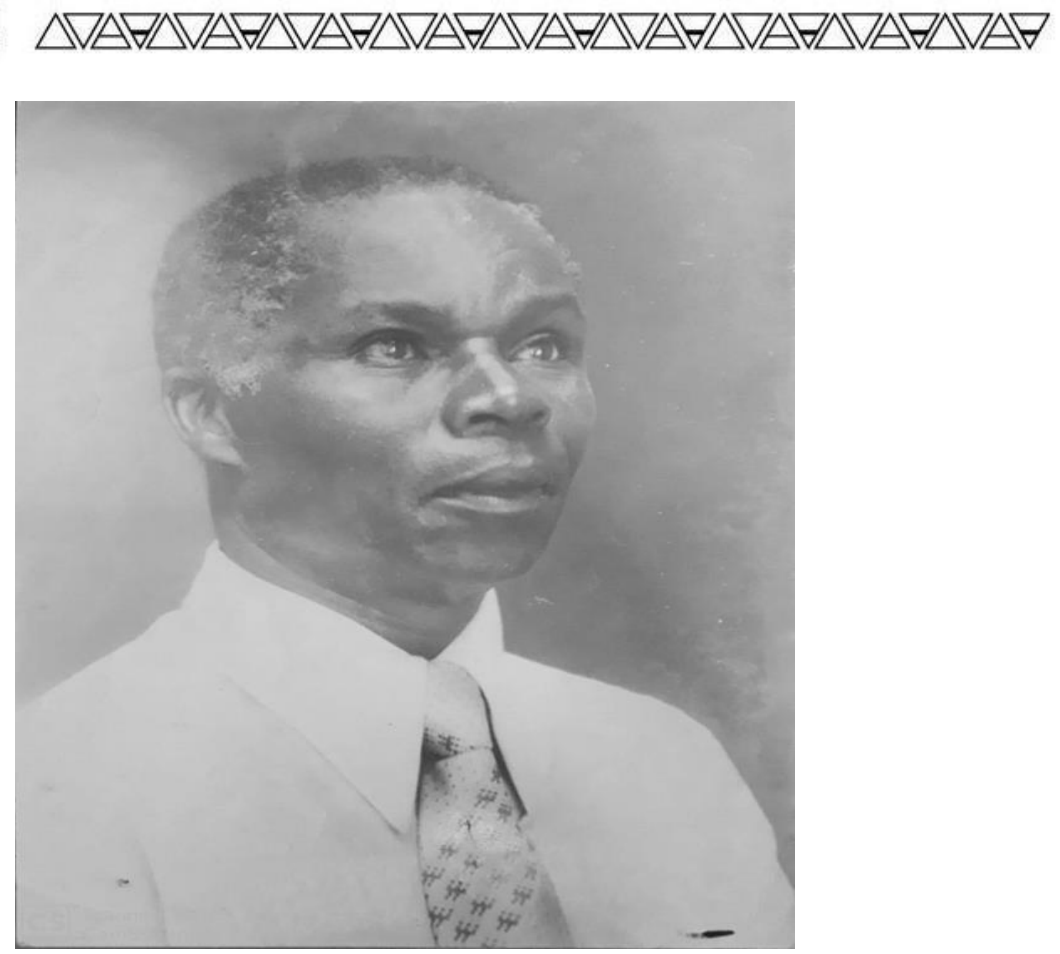

Fonte: Acervo familiar cedido ao Grupo de Pesquisa $\mathrm{O}$ recôncavo baiano no Mundo Atlântico: história, memória e patrimônio - UNILAB, junho de 2019.

\section{CONSIDERAÇÕES FINAIS}

Para o conhecimento histórico o sentido de tempo precisa ser pensado a longo prazo, sendo assim, é oportuno reconhecer que nosso passado escravista ainda está próximo cronologicamente, como expôs o historiador Flávio Gomes quando diz que "Para além da dimensão cronológica temos permanências e continuidades. O que mais tem de impacto é o racismo estrutural e estruturante da (e na) sociedade brasileira contemporânea (GOMES, 2019, p.1). Os diferentes contextos de pós emancipação no Brasil nos revelam importantes indícios para entender historicamente as hierarquias e desigualdades fundantes da sociedade brasileira. É seguro afirmar hoje em dia, que todos os momentos da história brasileira só podem ser entendidos a luz da história social da escravidão e dos processos de pós emancipação, sobretudo se forem articuladas e inclusas diferentes dimensões políticas, sociais, culturais e ideológicas, como por exemplo: a história do trabalho. Assim como bem advertiu Ira Berlin, "o estudo do local de trabalho oferece apenas um ponto de entrada prático em sua organização social” (BERLIN, 2006, P.19). Ao constatarmos que a vila de São Francisco do Conde foi estatisticamente um

Revista da ABPN • v. 12, n. Ed. Especial - Caderno Temático: "Africanos, escravizados, libertos biografias, imagens e experiências atlânticas" • agosto de 2020, 
reduto escravista persistente, podemos inferir o que viria no pós emancipação e como as gerações de famílias negras da região, tentaram por meio do trabalho galgar um futuro e uma inserção em um novo projeto de cidadania. No entanto, é importante perceber que a identidade laboral se refaz, reelabora e ajuda na busca incessante por dignidade.

\section{REFERÊNCIAS BIBLIOGRÁFICAS}

BAPTISTA, Karina Cunha. Diálogos dos Tempos. Memória da escravidão, história e identidade racial entre os afro-brasileiros, Dissertação de Mestrado em História, UFF, 2002.

BERLIN, Ira. Gerações de Cativeiro. Uma história da escravidão nos Estados Unidos. Rio de Janeiro: Record, 2006.

BARICKMAN, B. J. E se a casa-grande não fosse tão grande? Uma freguesia açucareira do Recôncavo Baiano em 1835. Afro-Ásia, nº 29-30. Universidade Federal da Bahia.

CASTELLUCI, Aldrin Armstrong Silva e SOUZA, Robério Santos. Os trabalhadores negros na História Social do trabalho no Brasil: o longo século XIX. In Histórias da Escravidão e do Pósabolição para as escolas. XAVIER, Giovana (org.) - Cruz das Almas: EDURFB; Belo Horizonte: Fino Traço, 2016. Pp.197-214.

CESAR COSTA MANOEL, Júlio. A Lei dos Sexagenários como estratégia para manutenção da Precariedade Socioespacial no Brasil. Revista da Associação Brasileira de Pesquisadores/as Negros/as (ABPN), [S.1.], v. 12, n. Ed. Especial, p. 12-31, abr. 2020. ISSN 2177-2770. Disponível em: <http://abpnrevista.org.br/revista/index.php/revistaabpn1/article/view/852>. Acesso em: 01 jul. 2020 .

CUNHA, Mário Pinto. Memorial de São Francisco do Conde. Prefeitura Municipal de São Francisco do Conde, 1976.

CHALHOUB, Sidney. Visões da Liberdade: uma história das últimas décadas da escravidão na corte. São Paulo: Companhia das Letras, 1990.

FERRERIA, Marieta e AMADO, Janaína (orgs). Usos e abusos da História Oral. Rio de Janeiro: FGV, 2008.

FRAGA, Walter. Encruzilhadas da Liberdade. Histórias de escravos e libertos na Bahia (18701910). Rio de Janeiro: Civilização Brasileira, 2014.

GIL, Lorena Almeida e KOSCHIER, Paulo Luiz Crizel (organizadores). A família Silva Santos e outros escritos: escravidão e pós-abolição ao Sul do Brasil. São Leopoldo: Casa Leiria, 2019.

GOMES, Flávio e SCHWARCZ, Lilia. Considerações sobre a Escravidão: Para ver mais: http://revistazcultural.pacc.ufrj.br/consideracoes-sobre-a-escravidao-lilia-schwarcz-e-flaviogomes/ Acesso em 12 de agosto de 2019.

Revista da ABPN • v. 12, n. Ed. Especial - Caderno Temático: "Africanos,

escravizados, libertos biografias, imagens e experiências atlânticas” • agosto de 2020, p. $563-590$ 
NETO, Pereira José: Sociedade, indenização e liberdade precária: os meandros burocráticos do fundo de emancipação de escravos (São Francisco Do Conde-Ba) -Campinas: Tese (Doutorado em História), Universidade Estadual de Campinas, 2018.

RIOS, Ana Lugão e MATTOS, Hebe. Memórias do Cativeiro. Família, trabalho e cidadania no pós-abolição. Rio de Janeiro: Civilização Brasileira, 2005.

SANTOS, Jair Cardoso dos. Candeias. História da Terra do Petróleo. Gráfica Salesiano, Salvador, 2008.

SCHWARCZ, Lilia Moritz; GOMES, Flávio dos Santos. Dicionário da escravidão e liberdade: 50 textos críticos $\left[1^{a}\right.$ ed.]. Companhia das Letras, 2018.

Recebido 03/07/2020

Aprovado em 22/07/2020

Revista da ABPN • v. 12, n. Ed. Especial - Caderno Temático: "Africanos,

escravizados, libertos biografias, imagens e experiências atlânticas” • agosto de 2020, 